\title{
Sustainable tourism development in rural and marginal areas and opportunities for female entrepreneurship: lessons from an exploratory study
}

\author{
Umberto Martini, Karin Malacarne, Silvia Pederzolli Giovanazzi and \\ Federica Buffa \\ Department of Economics and Management, University of Trento, Trento, Italy
}

\begin{abstract}
Purpose - The purpose of this paper is to analyse the role of female entrepreneurs in the development of sustainable tourism in marginal rural mountain areas. This role is studied with reference to two focal points: female entrepreneurs' involvement in the creation and management of tourism/hospitality services characterized by elements of authenticity, experientiality and innovation (Focus 1) and their willingness to create or participate in local stakeholder networks (Focus 2).

Design/methodology/approach - Exploratory research was conducted in mountain areas where tourism development is still marginal. In depth face-to-face interviews were conducted with 11 businesswomen in Trentino (Italy), who agreed to take part in this study.

Findings - Female entrepreneurs play a very important role in the development of sustainable mountain tourism. Elements of authenticity, experientiality and innovation are shown to be characteristic of female entrepreneurship, as is women's propensity to create and foster local stakeholder networks (directly or indirectly) linked to their own businesses.

Research limitations/implications - In the light of the exploratory nature of this study, a small convenience sample was used.

Originality/value - This research highlights specific features of female entrepreneurship related to the sustainable development of marginal rural areas and contributes to the academic debate on the topic. This topic is under-researched with regard to developed countries.
\end{abstract}

Keywords Female entrepreneurship, Sustainable tourism development, Rural and marginal areas, Trentino

Paper type Research paper

\section{Introduction}

This paper discusses the main findings of a study which investigates the role of female entrepreneurs in sustainable tourism development in marginal rural mountain areas. This study fits within the broader area of tourism as a driver of development in such areas and

(C) Umberto Martini, Karin Malacarne, Silvia Pederzolli Giovanazzi and Federica Buffa. Published by Emerald Publishing Limited. This article is published under the Creative Commons Attribution (CC BY 4.0) licence. Anyone may reproduce, distribute, translate and create derivative works of this article (for both commercial \& non-commercial purposes), subject to full attribution to the original publication and authors. The full terms of this license may be seen at http://creativecommons.org/licences/by/4.0/legalcode

The authors wish to thank "Accademia della Montagna del Trentino" (Mountain Academy of Trentino) for the financial support.

Sustainable tourism development

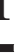


WHATT

12,4 examines the opportunities and criticalities around launching and developing women-led business activities. In the areas where the research was carried out - an Italian rural mountain area - traditional agri-pastoral and artisanal activities can no longer provide livelihoods for the resident population (Ruffini et al., 2011). In the absence of any medium and/or long-term plans for the places where they live, inhabitants must find ways to generate an adequate family income, given that business investment and entrepreneurial initiatives are largely absent. There is strong evidence that there is a (self-perpetuating) process of depopulation and a gradual abandonment of these mountain areas (Marini et al., 2011; Vogl and Vogl-Lukasser, 2014) which impacts local businesses and residents and inevitably results also in a decrease in the availability of basic services for local populations.

In this context, the research presented in this paper focusses on two phenomena:

(1) the possibility that the active involvement of women in the design, planning and management of tourism/hospitality services could allow guests to experience a sense of genuine welcome, based on low tourist numbers combined with high levels of empathy and engagement; and

(2) the propensity to create networks within the territorial micro-context, (directly and indirectly) involving other micro-entrepreneurs in the hospitality sector. These micro-entrepreneurs could be restaurants, small producers of food and artisan products, tourism guides specialized in facilitating the discovery of local place and culture, educators teaching courses related to various aspects of local knowledge. In this way, a shared supply micro-system is activated, which, being complimentary to the classic and traditional tourism services and activities, can really augment the tourism product and extend tourism experience.

This paper illustrates and discusses the main findings of an exploratory study on the role of female entrepreneurs in sustainable tourism development in marginal rural areas in Trentino (which is a region in the north-east of Italy). Trentino is a mountainous area which includes not only many mature tourist destinations, in terms of both infrastructure and business, but also marginal rural areas where the tourism potential has yet to be developed. The natural resources and beauty of these areas can be valorized to serve as pull factors for the creation of sustainable tourism models where there could be room for new micro-enterprise.

This research was conducted using a qualitative method based on personal interviews. In total, 11 key local businesswomen agreed to participate to this study, discussing topics related to their activities. These activities were linked to the tourism sector and to other closely related activities, such as agriculture and handicraft. Although limited by the small number of interviewees, this research reveals certain characteristics specific to female entrepreneurs that appear to be of relevance to the sustainable development of marginal rural areas. This last issue is an under-researched theme, particularly in developed countries with a strong industrial tradition and also a strong tourism sector.

\section{Literature review}

Two streams of literature help to frame the theoretical background of our research: sustainable tourism development in rural areas and the role that businesswomen can assume and the key factors in female entrepreneurship.

Sustainable tourism development in rural and marginal areas and female entrepreneurship: an overview

Pallarès-Blanch et al. (2015) identified two main types of mountain areas. Even if the natural environment is the dominant factor in both areas, they show large differences that can be 
appreciated even by sight. The first, called "tourism and building", is characterized by ski resorts and second houses that generate large flows of tourists. In contrast, in the second type of area, rural activities are dominant and tourism is marginal. Landscape and natural resources are confirmed to be distinctive pull factors for the utilization of rural mountain areas for tourism. Pallarès-Blanch et al. (2015) emphasize the central role of nature in local sustainable development strategies, while Osti and Cicero (2018, p. 211) affirm that "preserving and caring for the environment is imperative to the success of rural tourism". Mountain areas clearly provide an opportunity to promote a development approach which,

Sustainable tourism development

423 by adopting sustainable policies, respects place and delicate balances (environmental, sociocultural and economic). Prados (2009) used the term "naturbanization" to refer to the promotion and development of a territory attentive to environmental sustainability, seen as fundamental to local development and from this perspective, local government and policymakers should develop policies supporting the integration of innovative activities and services, leveraging local resources and traditions that communicate and promote the authenticity of the place.

The launch of female-led enterprises has been addressed in a number of interesting studies examining possible strategies and actions to foster sustainable development in marginal rural areas. Most of this research however has focussed on the issue, as it relates to developing countries. Studies by Bhuiyan et al. (2012), Greenberg et al. (2019), Ghouse et al. (2019), Kimbu et al. (2019) and Solanki (2019) investigate female entrepreneurship in rural areas in Israel, Oman, Africa and India, evidencing dynamics that apply in economic and socio-cultural contexts that are neither easily nor immediately comparable to those in developed countries (see Solanki, 2019). The literature on female entrepreneurs in marginal areas of industrialized countries is still scant.

Female entrepreneurs are active all over the world, and their activities are often presented as a real solution to the lack of labour in mountainous areas of the global north, as evidenced by Pallarès-Blanch et al. (2015). In a study carried out in rural Spain, the authors discovered that the contribution of female entrepreneurs had become essential to local development. Women often started businesses related to agriculture, food, tourism and health and well-being services. The research results reveal that more women than men were innovating although businesses begun by women were smaller and generated less revenue. Women, however, had to deal with stereotypical perceptions of the entrepreneur as a male figure, which sometimes mean that their entrepreneurial skills and potential go unrecognized.

A recent exploratory study of women's involvement in nature-based businesses in Sweden (Sörensson and Dalborg, 2017) highlights the main reasons why women start their own businesses. Two different drivers - push factors and pull factors - emerge from the study. The main pull factors are passion and independence, while the push factors are dissatisfaction with one's current circumstances and lack of any other option. Another reason is the desire of women to achieve a better balance between work and family. The research findings demonstrate that the majority of the women interviewed preferred to be their own boss rather than an employee, even when that meant shouldering greater work burdens and responsibilities. Another factor emerging from the study was the contribution of female entrepreneurial activity to innovation. Based on time in business (TB) and the extent of innovation (EI), four entrepreneurial profiles were identified: work training/green care (low TB and low EI); traditional business owner (high TB and low EI); hybrid entrepreneurs (low TB and high EI); and entrepreneurs (high TB and high EI).

Sörensson and Dalborg (2017) emphasize the importance of keeping business alive in these marginal rural areas, which otherwise risk being abandoned. Business development can contribute to the overall resilience of the territory and may increase its general well- 
WHATT

12,4

being. This evidence highlights the need to raise awareness of the conditions under which these businesswomen are working - it is a huge challenge for them to manage their work and families so that often they are forced to take time off work, with inevitable repercussions for their business. These business activities make a crucial contribution to the rural localities in which they are situated, creating jobs and increasing well-being.

In light of the above, we can better understand and appreciate the contribution that female entrepreneurs can make both to the economic development of marginal rural areas and to their own socio-cultural development and personal well-being.

\section{Authenticity and networking as key factors in female entrepreneurship}

According to a study carried out by the Center for Creative Leadership on a group of female managers and executives, one of the main factors influencing the career and life of a woman is "authenticity" (Ruderman and Rogolsky, 2014). People achieve authenticity by harmonizing their behaviours with their values: authentic women are aware of themselves and of their own priorities. Ruderman and Rogolsky's notion of authenticity is defined as a combination of five characteristics:

(1) clear values, priorities and preferences;

(2) acceptance of the need to make choices and trade-offs;

(3) strong sense of self-determination;

(4) desire to align values and behaviours in one's professional life; and

(5) high level of comfort and satisfaction with one's previous choices.

Women with a high sense of authenticity have a clear vision of what success means and how they identify as being personally successful; they try to manage their lives in harmony with their priorities. To illustrate the point, two cases are described: one of a woman who decided to spend more time with her children at the expense of her career, and the other of a mother who chose to spend less time at home to achieve her professional goals. Most of the women who had reached an understanding of their authentic selves had fewer regrets about the choices they had made and how they were living their lives.

In the literature, women-led businesses are characterized by "feminized entrepreneurial identity" (Lewis, 2013). According to Lewis' study (2013) on gender, work and organization, entrepreneurial identity is linked to women's social position and to the continuous fight between the private sphere of home and family and the public sphere of business and work. This modus operandi emphasizes intimacy: the aim is to create relationships based on cooperation and the exchange of ideas and opinions. Women tend to create human connection and relationships based on "co-operation and exchanges" (Lewis, 2013). Authenticity, according to the study, arises from the feminine attitude and the quality of intimacy, which are innate in women and have been reached owing to personal experiences. Women have a clear idea of the sort of business person they want to be, and their work is guided by an authentic identity. Businesswomen create an authentic identity for their businesses through certain practices such as listening to their co-workers, dealing with people in an open manner, building long-term relationships and developing empathy for the people with whom they work.

Businesswomen, therefore, create an ethical environment for themselves in which they have a clear sense of how to operate in accordance with their own value system. An enterprise with an authentic identity is attentive to the context where it operates and its boss clearly establishes the kind of person she wants to be, and her behaviour is spontaneous and natural. 
A second factor highlighted in the literature is the capacity of businesswomen to create and foster networks. Many studies demonstrate the extent to which network creation in the workplace benefits the business concerned. The advantages of a network are numerous (Drakopoulou Dodd and Keles, 2014) and include the greater likelihood of becoming aware of available opportunities, the strengthening of stakeholder relations and the exchange of ideas and opinions.

A study by Greguletz et al. (2019), carried out in Germany, found that male and female networks operate differently and at different levels of efficiency. The findings of the study demonstrate that the relationships between women are less numerous but stronger, while those between men are more numerous. Men tend to create professional relations with anyone who might be in a position to help them to reach their particular goals; in contrast, women place more importance on ethical factors when building networks.

A study undertaken by Hechavarria and Ingram (2016) found a significant positive correlation between females and attitude towards selecting social organizational forms. These kinds of organizations are positively connected with feminine normative values, while for males, it is the opposite, in the sense that values are negatively correlated to "hegemonic masculinity". Therefore, although both female and male entrepreneurs might prefer a commercial form for their business, this study underlined how the distinction in gender could determine a different approach to organizational forms.

Participation in networks may be crucial to the operation of a business. Women create fewer business relationships than men and are less embedded in networks (Klyver and Grant, 2010). They usually make their first contact with male entrepreneurs of the same sector but then their ongoing connections are often with other women in the same business field. Men, on the other hand, tend to make contact exclusively with other men. Klyver and Grant's (2010) research highlights the importance of participating in a network and demonstrates that levels of participation vary depending on the stage of the business. Networks play a much more significant role in a business's success in the birth phase, becoming less necessary in subsequent stages.

Manello et al. (2019) observe that the business networks in which women are active are more effective than those of men, and men's networks are more traditional. In fact, networking appeared to be an effective way to improve business performance when a woman-led enterprise is operating in a predominantly male environment where businesswomen tend to face greater challenges. At the conclusion of the study, the authors affirm that networking is crucial to success for any businesses, whether large or small, traditional or innovative.

\section{Research methodology: study area and contact method}

This study examines the contribution of female entrepreneurs in marginal mountainous areas, focussing specifically on firms in the tourism, agriculture and artisan sectors. This exploratory research was carried out in Trentino, a mountainous area in northern Italy. In 2019, this area hosted 9,150 women-led businesses that account for 18\% of all firms (Trento Chamber of Commerce, first semester of 2019). More than $60 \%$ of women-led businesses are active in one of these sectors: $17 \%$ in tourism, $23 \%$ in agriculture and $21 \%$ in the artisan.

This research investigates the role of female entrepreneurs and their involvement in the creation and management of tourism and hospitality services characterized by elements of authenticity, experientiality and innovation (research focus 1) and their propensity to create, or participate in, local stakeholder networks to expand tourism services and the territory's tourism offer (research focus 2). 
WHATT

12,4

426

The use of a qualitative interviews permitted us to capture the strengths and weaknesses of the business start-up and management stages and to discuss any innovative and/or prosustainable choices made. The analysis of the latter factor relies on a study by Epifani et al. (2006) which discussed the physical, cognitive, communicative and behavioural dimensions of the innovation:

- Physical dimension includes product, process, structure and organization.

- Cognitive dimension includes competence, creativity, skills and strategy.

- Behavioural dimension refers to action plans, decisions, motivations and performance.

- Communicative dimension focusses on notions of information, knowledge, interpretation and goals.

The businesses relevant to our analysis were identified using a convenience sample. Based on the data provided by the Trento Chamber of Commerce (for the first semester of 2019) and having consulted stakeholders with particular knowledge of local womenled businesses, the units were selected for the three sectors: tourism, agriculture and handicraft.

The exploratory nature of the research led us to favour personal interviews in situ, a solution that allowed us to collect very detailed information and insights. In these personal, semi-structured interviews, we could discuss in detail factors such as authenticity, experientiality, innovation and the businesswomen's contribution to local tourism development.

We identified the female entrepreneurs to be contacted in accordance with the following criteria:

- Location: the businesses chosen were located in marginal mountain areas where tourism is still underdeveloped.

- Business development: the chosen businesses have achieved successful goals during their business career (for example, the introduction of new local products/ services).

- Company size: microbusinesses (as defined by EU Commission, business with less than ten employees) were chosen so that we could capture the role and involvement of the businesswomen in the management of the firm and in networking with local stakeholders.

As summarized in Table 1, we chose three female entrepreneurs in the tourism sector, three in the artisan sector and five in agriculture. The interviewees are between 31 and 60 years old; the majority of them were employed before starting their own business. One has no

Table 1.

Number of womenled businesses in Trentino and number of interviews divided by sector

\begin{tabular}{lccc}
\hline Sector & Number of firms & Firms per sector & Number of interviews \\
\hline Tourism & 1,456 & $17 \%$ & 3 \\
Agriculture* & 1,927 & $23 \%$ & 5 \\
Artisan & 1,743 & $21 \%$ & 3 \\
Total & 5,129 & $61 \%$ & 11
\end{tabular}

Source: "Agritourism" enterprises are included under "Agriculture". Authors' elaboration of data from the CCIAA in Trento (2019) 
children and the rest have between one and three children. More than half have a secondarylevel diploma. All of them are satisfied by the choice they have taken to run their own business.

\section{Findings}

This study investigates the role and contribution of businesswomen in sustainable tourism development in marginal mountain areas. In relation to the two research focal points, the results reveal that female businesses are characterized by elements of authenticity, experientiality and innovation, and that businesswomen tend to form and sustain local stakeholder networks (directly and/or indirectly) connected to their own businesses.

The findings demonstrate that the businesswomen who participated in the research have often faced critical periods and challenges linked to economic and bureaucratic factors, as well as to the difficulty of balancing their private and professional lives. In spite of everything, their notable strength and determination has allowed them to reach their goals and then create new ones, and in so doing, they have been able to steadily expand and refine their businesses. The main motives that induced these women to launch their businesses are linked to their passion and self-realization, that is, to those dimensions described in the literature as pull factors (Sörensson and Dalborg, 2017).

The reconciliation of work and home and how to manage their families remain key questions for businesswomen everywhere. This factor emerged as an additional challenge which almost all 11 interviewees have to manage. Differently from men, businesswomen often involve family members in their businesses (in line with the findings of Klyver and Grant, 2010), while beyond the family sphere, businesswomen seek out relations with the local community and other local micro-businesses.

The interviews revealed an interest in both the creation of a network of stakeholders - in areas without existing networks - and a desire to join existing networks. In total, 7 of the 11 interviewees were already part of a network of local tourist businesses and services. Of the other four women, three wanted to create a network and believed that it was essential for the growth of their own business. Women interviewed emphasized the importance of the main territorial marketing firms - those who already counted one of these businesses in their network recognized the significance of their participation, while those who were not yet linked to one of these firms said that they wanted to include them in their network. Networking is thus considered as strength for these mountain-based enterprises, as not all necessary resources are always available, and networks can be a valuable means for sharing the benefits, services, resources - and challenges - of the market place.

Our research reveals a relation between the businesswomen's actions and their attitudes towards innovation and sustainability. The women interviewed demonstrated strong interest in environmental protection, and they all said that they adhere to sustainable practices to preserve the natural world around them. Their statements clearly showed that they have sought to incorporate a range of innovative features into their businesses. Innovation emerged as a strength in all the observed cases. All the businesswomen said that they had brought something new to the territory, or that they had actually invented something entirely original. A variety of innovative philosophies and/or proposals for action of the types described in Epifani et al.'s study (2006) were mentioned by the interviewees. Each of the businesses considered is - to some degree - innovative; some examples are the first shop in the mountains of Trentino to sell fresh, zero km, plastic-free products, running events where farmers and growers can share knowledge and expertise, distribution of products through local food networks and the use of social media platforms to market products, with an emphasis on their sustainability.

\section{Sustainable tourism development}


WHATT

12,4
In sum, most of the businesswomen interviewed have adopted actions oriented towards social and environmental sustainability, both in choosing what their final product would be and/or in choosing the primary materials to be used and/or in the provision of their services/ products. The most frequently adopted innovations relate to the physical dimension (products and structures in particular) and a smaller number relate to communication. The latter dimension still appeared to be under-valued by the interviewees although it has proved very effective for some enterprises and can be seen as one of their success factors. A small number of innovations have also occurred in the cognitive dimension, that is, the valorization of formerly unacknowledged competences. Finally, some innovative behavioural factors are evident, in particular related to internal decision-making and motivation. Overall, we see innovations linked not only to product and process (although these are the most prevalent) but also to information, knowledge, leadership, cooperation and relational aspects. The cases observed demonstrate that sometimes, even though no new services or products have been introduced, novel methods or methodologies have been adopted, such as networks of local farm businesses and the collaboration between artisans and farmers.

\section{Conclusions}

The research reveals the role played by female entrepreneurs in sustainable tourism development in marginal rural areas in Trentino. Women-led businesses are particularly numerous in the tourism, agriculture and artisan sectors, and their contribution to the socioeconomic development of marginal areas is very significant. These enterprises have a considerable impact on local development, encouraging both other women and young people not to migrate and thus mitigating the depopulation of the mountain areas in question. Women-led businesses are much more likely to be backed by personal/family capital, be headquartered in the family home and involve forms of labour that overlap everyday work (agriculture, hospitality, well-being services). The literature particularly emphasizes that these initiatives allow women to transform the traditional female roles into paid work, translating their passions, skills and knowledge into economic activity (O’Toole and Macgarvey, 2003). The observed cases reveal the strength of these businesswomen, who believe wholeheartedly in what they are doing and never give up, whatever the challenges. They are all scrupulous in their attention to detail and product/service quality, regardless of the extra time and expense involved in maintaining such high standards.

The research findings demonstrate how these women have introduced novel, sustainable elements into the market place and how female authenticity has given their activities additional value, recognizing these elements to be vital to the success of their businesses. Moreover, a bond with their local territory is also evident, not only in relation to the service and/or product created but also to the capacity to build collaborative networks with other local micro-enterprises and marketing companies.

The importance of generating inputs to attract new members to a network and the creation of financial assets which permit the network to undertake new projects should not be ignored (Chatzitheodoridis et al., 2016).

Despite the limitations inherent in the exploratory nature of this research, we believe that it contributes to the academic debate on the opportunities offered by female entrepreneurship for sustainable tourism development in marginal areas. The extension of this research to representative samples of women-led enterprises would enable further investigation of this topic. 


\section{References}

Bhuiyan, M.A.H., Siwar, C., Ismail, S.M. and Islam, R. (2012), "Home stay accommodation for tourism development in east coast economic region”, American Journal of Applied Sciences, Vol. 9 No. 7 , pp. 1085-1090.

Sustainable tourism development

Chatzitheodoridis, F., Kontogeorgos, A., Liltsi, P., Apostolidou, I., Michailidis, A. and Loizou, E. (2016), "Small women's cooperatives in less favored and mountainous areas under economic instability", Agricultural Economics Review, Vol. 17 No. 1, pp. 63-79.

Drakopoulou Dodd, S. and Keles, J.Y. (2014), Expanding the Networks of Disadvantaged Entrepreneurs. A Background Paper for the OECD Centre for Entrepreneurship, SMEs and Local Development, OECD-LEED.

Epifani, S., Hilgenberg, K., Sabbadin, E. and Warschat, J. (2006), Decidere L'innovazione. Come Misurare, Valutare e Scegliere il Cambiamento, Sperling and Kupfer.

Ghouse, S.M., McElwee, G. and Durrah, O. (2019), "Entrepreneurial success of cottage-based women entrepreneurs in Oman", International Journal of Entrepreneurial Behavior and Research, Vol. 25 No. 3, pp. 480-498.

Greenberg, Z., Arnon, S., Shamai, S. and Schnell, Y. (2019), "Women's entrepreneurship and small businesses in rural settlements in the Israeli Northern periphery", Romanian Journal of Geography, Vol. 63 No. 1, pp. 65-82.

Greguletz, E., Diehl, M. and Kreutzer, K. (2019), "Why women build less effective networks than men: the role of structural exclusion and personal hesitation", Human Relations, Vol. 72 No. 7 , pp. 1234-1261, doi: 10.1177/0018726718804303.

Hechavarria, D.M. and Ingram, A.E. (2016), "The entrepreneurial gender divide: hegemonic masculinity, emphasized femininity and organizational forms", International Journal of Gender and Entrepreneurship, Vol. 8 No. 3, pp. 242-281, doi: 10.1108/IJGE-09-2014-0029.

Kimbu, A., Ngoasong, M., Adeola, O. and Afenyo-Agbe, E. (2019), "Collaborative networks for sustainable human Capital management in women's tourism entrepreneurship: the role of tourism policy", Tourism Planning and Development, Vol. 16 No. 2, pp. 161-178.

Klyver, K. and Grant, S. (2010), "Gender differences in entrepreneurial networking and participation", International Journal of Gender and Entrepreneurship, Vol. 2 No. 3, pp. 213-227.

Lewis, P. (2013), "The search for an authentic entrepreneurial identity: difference and professionalism among women business owners", Gender, Work and Organization, Vol. 20 No. 3, pp. 252-266.

Manello, A., Cisi, M., Devicienti, F. and Vannoni, D. (2019), "Networking: a business for women”, Small Business Economics, doi: 10.1007/s11187-019-00300-3.

Marini, L., Klimek, S. and Battisti, A. (2011), "Mitigating the impacts of the decline of traditional farming on mountain landscapes and biodiversity: a case study in the European alps", Environmental Science and Policy, Vol. 14 No. 3, pp. 258-267, doi: 10.1016/j.envsci.2010.12.003.

O'Toole, K. and Macgarvey, A. (2003), "Rural women and local economic development in SouthWest Victoria”, Journal of Rural Studies, Vol. 19 No. 2, pp. 173-186, doi: 10.1016/S0743-0167 (02)00072-4.

Osti, L. and Cicero, L. (2018), “Tourists' perception of landscape attributes in rural tourism”, Worldwide Hospitality and Tourism Themes, Vol. 10 No. 2, pp. 211-221, doi: 10.1108/WHATT-12-2017-0087.

Pallarès-Blanch, M., F. Tulla, A. and Vera, A. (2015), "Environmental capital and women's entrepreneurship: a sustainable local development approach", Carpathian Journal of Earth and Environmental Sciences, Vol. 10 No. 3, pp. 133-146.

Prados, M.J. (2009), "Conceptual and methodological framework of naturbanization", in Prados, M.J. (Ed.), Naturbanization: New Identities and Processes for Rural-Natural Areas, Taylor and Francis, London, pp. 11-28.

Ruderman, M.N. and Rogolsky, S. (2014), Getting Real. How High-Achieving Women Can Lead Authentically, Center for Creative Leader. 
WHATT

12,4

Ruffini, F.V., Streifeneder, T., Hoffmann, C. and Stiefenhofer, A. (2011), "Agriculture in the alpine arc", in Scaramellini, G. and Dal Borgo A.G. (Eds), Changing Alps between Risks and Change. Innsbruck, Innsbruck University Press.

Solanki, N. (2019), "Women entrepreneurship: a paradigm shift", Humanities and Social Sciences Reviews, Vol. 7 No. 1, pp. 501-504.

Sörensson, A. and Dalborg, C. (2017), "Female entrepreneurs in nature-based businesses: working conditions, well-being, and everyday life situation", Society, Health and Vulnerability, Vol. 8 No. sup1, doi: 10.1080/20021518.2017.1306905.

Vogl, C.R. and Vogl-Lukasser, B. (2014), "Local knowledge in the alps about traditional crops and local varieties”, Documentation of Forum Alpinum 2014 “Alpine Resources”, Darfo Boario Terme, 17 19 September 2014, pp. 6-7.

\section{Further reading}

Camera di Commercio Industria e Artigianato di Trento (2019), "Stabile il numero di imprese guidate da donne", available at: www.tn.camcom.it/sites/default/files/uploads/documents/ComunicatiStampa/ Anno_2019/19CSImprenditoriaFemminile2018.pdf (accessed 30 April 2020).

\section{Corresponding author}

Federica Buffa can be contacted at: federica.buffa@unitn.it

For instructions on how to order reprints of this article, please visit our website: www.emeraldgrouppublishing.com/licensing/reprints.htm Or contact us for further details: permissions@emeraldinsight.com 